\title{
The Dynamics Policy of the Deputy Head of Region in the Implementation of Local Government
}

\author{
Khairul Rahman \\ Department of Government Science \\ Islamic University of Riau \\ Pekanbaru, Indonesia \\ Student of Doctoral Program at Padjadjaran University \\ khairul_rahman87@yahoo.co.id
}

\author{
Dede Mariana \\ Department of Government Science \\ Padjadjaran University \\ Bandung, Indonesia \\ dedemariana@yahoo.com
}

\begin{abstract}
Dynamics of the position policy of the deputy head of the region related to policy change and policy development. The implementation of local government in Indonesia especially after the 1998 reforms was marked by an unhealthy relationship between the Regional Head and Deputy Regional Head in several regions in Indonesia. The unharmonious relationship or conflict has negative implications in the administration of government, let alone both are leaders who gain legitimacy from the community and also both have a responsibility in legislation to work together in order to run the affairs of local government. The existence of the deputy head of the region is always interesting to be discussed by many parties, especially by academics and policymakers. Conflicts between the regional head and the deputy head of the region that occurred so far did not escape the dynamics of policy on local government that has been in force and regulate the position of deputy regional head. So this paper is present to photograph the dynamics of the policy of the position of deputy head of region in the implementation of local government in Indonesia.
\end{abstract}

Keywords - Dynamics of Policy; Deputy Head of Region; Local Government

\section{INTRODUCTION}

The implementation of local government after the 1998 reform was faced with the problem of disharmonic relations between the regional head and the regional deputy. In some areas, the disharmonic relationship between the regional head and the deputy regional head has disrupted the stability of local governance.

Conflict between the regional head and the deputy head of the region has an impact on the non-role of the deputy head of the region in carrying out its duties, so that the existence of the post of deputy head of region began to be discussed and has encouraged a study that sees the existence of deputy head of regional office by many parties. As said by Wasistiono (2013:2) The controversy over the presence of the deputy head of the region is actually nothing new. From various legislative drafting on decentralization, the controversy is always emerging and controversial.

This picture is at least in line with the data of the Ministry of Home Affairs, which is 92 percent of the regional heads and deputy heads of regional heads before the 2010 and 2011 elections, with 8 percent remaining in the next election (Labolo 2015: 121). The disharmonic relationship between the regional head and the deputy head of the region that occurred so far has not escaped the dynamics of public policy regarding the existing regional government and regulates the position of deputy regional head. Until now there are twelve policy instruments that have regulated the position of deputy head of region in the implementation of local government. Currently, the position of deputy head of region is regulated in Law Number 9 The Year 2015 on the Second Amendment to Law Number 23 The Year 2014 About Local Government.

Understanding the dynamics of the policy of the post of deputy head of the region trying to illustrate why the policy changed? What is behind the change? This is what is important to be understood in the dynamics of public policy. As John (2003: 482) suggests, the dynamics of public policy relate to understanding and explaining why certain policies change and others are not (stable); why policies have different consequences to the public.

The dynamics of the position policy of the deputy head of the region tried to analyze why the policy changes and the development of policy. This is possible because it has been happening for a long time (the dynamics of the policy cannot be seen in a short time), an interesting thing that after the independence of the Indonesian Republic and the reform of 1998 there have been several changes and policy developments related to the position of deputy head of region in the instrument policy in the form of law on local government. Ndraha (2009: 21 ) asserts that dynamics is the rate of speed and accuracy of change (adaptability) of relationships between subcools from heterostatic conditions to homeostasis and vice versa. While Nugroho (2009) said the dynamics of public policy is the consequence of public policy interaction with the political, economic, social, and cultural conditions in which the policy is located and the dynamic character of public policy as a result of synthesis of political, economic, social and cultural dynamics in which public policy is.

The policy dynamics of the deputy head of the region is not to provide a supposed assessment and so on but is intended to photograph the changes that will result in a useful pattern for policy makers to formulate policies related to heads of deputy regional heads. Policy makers have sufficient capital to know the patterns and consequences. The purpose is to do dynamic analysis as it says key (2006: 4) to compare a system as it passes through consecutive temporal states, and these consecutive states may come slowly or quickly; thus a system that changes slowly would have different temporal identifiers to one that changed quickly.

In the policy process so far has not been able to show or explain what prompted the policy of the position of the deputy head of the region changed and developed from one 
stage to the next (static) only photographed stages such as policy agenda, formulation, implementation, and evaluation so that required analysis of dynamics of policy deputy head of region.

\section{POLICY CHANGE AND POLICY DEVELOPMENT DEPUTY HEAD OF REGION}

The existence of the position of deputy regional head in local governance is very dependent on the instrument of law which regulates the "regional government" starting from the independent Indonesia until now there are twelve policy instruments in the form of Law and Presidential Decision which regulate the "regional government" related to the position of deputy head of region, can be explained as follows:

1. Law Number 1 The Year 1945 Concerning the Position of National Committee of the Region

This law is still very simple, so it has not set the position of deputy head of the region, due to the presence of Law No. 1 The Year 1945 with the consideration of the previous election held need to be made provision for a while to establish the position of the National Committee of the Region. Although simple, at this time the position of the deputy head of the region has been limited to replace the head of the region if the head of the area is absent.

2. Law Number 22 The Year 1948 Concerning Stipulation of the Main Rules Concerning Self-Government in Areas Eligible to Arrange and Maintain Their Own Households

At this time there can be no position of deputy head of the region, except for the Special Region, even it is not absolute must exist, mentioned in Article 18 paragraph (6) Law No. 22 of 1948: "For a special region may be appointed a Deputy Head of Region by the President. the deputy head of the Special Region is a member of the Regional Government Council. Thus the position of the deputy head of the region is not determined or with the exception of this. At this time if the head of the region is absent, the Regional Government Council shall be appointed by one of its members to represent the regional head. But the appointment does not result in the birth of a new position (deputy head of region). The appointed member of the governing council remains a member of the government council.

3. Law Number 1 The Year 1957 on the Principles of Regional Government

Not much different from Law No. 22 The Year 1948 above, At this time there is no position of deputy head of the region, except for a special area may be appointed deputy head of the region (it is not absolutely necessary). Article 25 Paragraph (2): For the Special Territory, may be appointed from a candidate submitted by the Regional People's Legislative Assembly of a Special Vice-President appointed and dismissed by a ruler who removes the Head of the Special Territory, with due regard to the conditions.

4. Determination of President Number 6 The Year 1959 About Local Government

Determination of President No. 6 of 1959 which further strengthens the position of deputy head of region for the Special Region. Basically, it does not change the substance that existed in Law No. 1 The Year 1957.

5. Determination of President Number 2 The Year 1960 About the Deputy Regional Head Level I

At this time the post of deputy head of the region began to be considered important. According to CST Kansil
(1979:81) in general, Swatantra areas do not have a vice regional head. However, for some areas of Swatantra level, I held the position of deputy head of the region given the importance and position of the Daswati. Presidential Decree No. 2 of 1960 set the deputy head of the region for the first level, because not yet set in Presidential Decree No. 6 The Year 1959. The existence of the deputy head of the region is necessary for the smooth running of local government and regional development. Since April 1960, the areas of Swatantra Level I: Jakarta Raya, West Java, Central Java, East Java and North Sumatra have been appointed to each of these areas a deputy regional head (Guyanie, 2014:73).

6. Law Number 18 The Year 1965 on the Principles of Regional Government

At this time the position of deputy head of the region is determined to exist in the implementation of local government. In Article 6 of Law Number 18, The Year 1965 explicitly states: "In carrying out the daily administration of the Head of Region assisted by the Deputy Head of Region and Government Agency Daily. Further Article 47 paragraph (2) states that: "The Deputy Head of Region assist the Regional Head in carrying out his duties of daily authority according to the guidance given by the Minister of Home Affairs. At this time the number of deputy head of region is determined at least two and as many as four people taken from the element of the Regional House of Representatives (DPRD).

7. Law Number 5 The Year 1974 on the Principles of Regional Government

To be differentiated by the law number 18 of 1965 previously, where at this time the deputy head of the region is taken from elements of Civil Servants (PNS) that meet the requirements, different from previously drawn from the candidate Regional House of Representatives (DPRD). Deputy head of the region is certainly by obtaining the approval of the regional legislative assembly without going through the election. Filling the position of deputy head of the region conducted according to need. Its tentative nature, is not a necessity, while the amount depends on the need. deputy head of region is a state official. It is clear at this time that the presence of a deputy head of the region is not a necessity other than that the amount is not specified in the law.

8. Law Number 22 The Year 1999 regarding Regional Government

At this time it was argued that each region was led by a regional head as chief executive assisted by a deputy head of the region. So in this law re-affirmed the necessity of filling the position of deputy head of the region but its nature is not tentative as in the period of Law no. 5 The Year 1974 means determined only one person deputy head of the region. Furthermore, filling the position of the regional head and deputy head of region conducted by the Regional People's Legislative Assembly (DPRD) through the election simultaneously not direct selected by the community. In Article 57 paragraph (1) of Law Number 22 The Year 1999 mentioned Regarding the duty of the deputy head of the region to assist, coordinate and carry out other tasks given by the head of the region. In addition, a deputy head of the region is responsible for the regional head. So even though selected in one package, the deputy head of the region other than as an alter-ego is also subordinated to the head of the region.

9. Law Number 32 The Year 2004 regarding Regional Government

The law also asserts that the regional head is assisted by a deputy regional head. In performing his duties the Deputy 
Head of Regional Government shall be responsible to the Regional Head. In contrast to the previous law, the position of the deputy head of the region was directly elected by the community, where the head of the regional office was drawn from the political party elements carried by the pattern of a package of candidate pairs of regional heads and deputy regional heads. Deputy regional heads have a more complex task compared to previous laws: Assisting the Regional Head in organizing a local government, coordinating, monitoring and evaluating, providing advice and considerations.

10. Law Number 12 The Year 2008 regarding the second amendment to Law Number 32 The Year 2004 regarding Regional Government

At this time there is only an additional explanation (paragraph) relating to the filling of the position of deputy head of the region in case of vacancy of the position of deputy head of region, the provision of Article 26 of Law 32 Year 2004 in this law plus 4 (four) verses, namely paragraph (4), paragraph (5), paragraph (6), and paragraph (7).

\section{Law Number 23 The Year 2005 regarding Regional} Government

At this time it was stated that the regional head could be assisted by the deputy head of the region. This law indicates that there should not be a position of deputy regional head, where Article 63 paragraph (1) mentions the Regional Head can be assisted by the deputy head of the region. However, in the course of this provision (Article 63 Paragraph 1) cannot be executed because it is amended by Law No. 9 of 2015 concerning the administration of a region where one of its substance is to arrange a chapter related to the position of deputy head of region returning to the form of a 32-year law 2004 which mentions the head of the region as assisted by the deputy head of the region, in addition there are articles in Law No. 23 of 2015 which amended and added, namely article 66 associated with the post of deputy head of the region.

12. Law Number 9 The Year 2015 on the Second Amendment to Law Number 23 The Year 2014 on Regional Government

At this time it seems still adopted the pattern in law 32 of 2004 there are only additional provisions related to the position of deputy head of the region. The Deputy Regional Head in carrying out his duties is required to sign an integrity pact and be accountable to the regional head (Article 66 Paragraph [3]). It also contains an emphasis stating that the deputy head of the region is obliged to carry out joint tasks with the regional head until the end of his tenure (Article 66 Paragraph [4]). It can be emphasized that the task of the deputy head of the region at this time is also very complex which means the vice regional head also plays an important role in the regional government

\section{DISCUSSION}

The dynamics of the policy of the position of the deputy head of the region in order to create a harmonious, effective and efficient governance in Indonesia is always related to philosophical questions; required or not deputy head of region? If required how much? From what element is the deputy head of the region taken and how the process of filling it? What is the pattern of the employment relationship or the division of labor between the regional head and deputy regional head? To who is the deputy head of the region responsible and how is the responsibility? How is the allocation of financing the position of deputy head of the district?
Am empirical phenomenon in the field shows the disharmonic relationship between the regional head and deputy head of the region began to be a concern and then discussed in various forums and media after the reform era of 1998 associated with the existence of the post of deputy head of the region. In the pre-reform period of 1998 the implementation of local government as regulated in several laws, one of which is Law No. 5 of 1974 related to the policy of the regional head and vice regional heads, there is almost no relationship of disharmony or conflict between the regional head and vice regional head, even the presence of representatives strengthens the position of the regional head in the administration.

The policy instrument for the position of regional deputy head (Law) should be able to create an atmosphere of governance between the regional head and the more harmonious representative, if this does not get the attention then the conflict between the regional head and deputy head of region will weaken the functioning of the government which is full of political conflict and interests. As stated by Ramadhan (Journal of Governance, 2006:9597) said that seeing the unharmonious conditions between the regional head and the deputy head of the region, there are various impacts that arise, including (a) The emergence of internal conflict between the head of government and his Deputy; (b) Policies that are not in parallel; (c) Unstable Government; (d) neglect of public interest; and (d) Reduced public confidence in the government. Conflict between the regional head and the deputy head of the region clearly disrupts the development process in the region (Nugraha, 2013:152)

From some laws regulating local government in Indonesia related to the position of Deputy Head of Region there are three patterns of difference in general, First, the initial period of refueling indicates there is no position of deputy head of region (there is only for the special area) and if there is still is simple. Second, the new order period in which the position of deputy head of region was held to assist the head of the region with the number tentative and appointed from state officials (ASN). Third, the period of reform in 1998 in which the presence of the deputy head of the region is a necessity that can be taken from anywhere eligible and selected in a package of candidate pairs, in addition, the deputy head of the region has a complex task but full of controversy with colored disharmonic relationship between regional head and deputy regional head.

The implementation of the policy on regional government, especially after the reforms, namely Law Number 22 Year 1999, Law Number 32 Year 2004, Law Number 12 Year 2008, Law 23 Year 2015 and Law Number 9 Year 2015 should provide pattern of good / harmonious working relationship between the regional head and vicel of regional head and answer the existence of the position of the deputy head of region in the implementation of local government. According to Nugraha (2013: 146), the division of roles among his tribes has also been governed by the provisions of the legislation, should not in detail set about it. In fact, however, the law in its application places the position of the deputy head of the region in a position which creates vulnerability both with regard to the relationship with the regional head and in performing his duties as the deputy head of the region, generally due to the regional head and deputy regional heads of different parties and not the existence of chemistry because it is determined unilaterally from the party bearer to win the vote in the election.

The search for the appropriate format related to the position of the deputy head of the region should be the main objective by observing the dynamics of the position policy of the deputy head of the region (the pattern 
formed), because the confusion between the regional head and the deputy head of the region will still be very possible, let alone the regulation made does not give appropriate solutions, as well as the development of commitments and responsibilities in governance. As Key (2006: 4) notes in the introduction of this paper, the dynamics of the viceprovincial position policy of identifying the changes of a period with the next one there is a quick one with the slope of each pattern and explanation of the determination of a choice is taken.

The existence of changes and the development of the policy of the position of deputy head of region and the empirical phenomenon, especially related to the unharmonious relationship between the regional head and the deputy head of the region needed an explanation of the dynamics of the policy. The Dynamic public policy deals with two things: policy change and policy development. As has been previously asserted to understand the dynamics of the policy, the important thing that must be understood first is why the policy is changing? What is behind the change? This is what is important to be understood in the dynamics of public policy. Stachowiak (2013) explains the underlying assumptions of policy changes namely: a). Coalitions undertaken together with agreement on core beliefs about policies, secondary beliefs about how policies are implemented are less critical of regulation (eg, administrative rules, budget allocations, revisions of legislation); b). Multiple groups can operate effectively and efficiently because of their shared core beliefs; in other words, less time is needed to achieve a common understanding; c). The policy core is resilient to change, except for major external events, such as changes in socioeconomic conditions or public opinion, which are skillfully exploited by proponents of change; or new learning about the policies that emerge on the coalition that changed the view of it; d). Policies are unlikely to change unless the support groups of the status quo are no longer in power, or changes made by the superior hierarchy of jurisdiction.

Understanding the policy changes can be seen from understanding stability and change. There is an inherent paradox that explains changes in the system that indicate the inherent quality of stability. Dudly and Jeremy Richardson (1945: 120) say the policy change is largely determined by a so-called stability order, an abnormal stability condition will allow or be certain that policy changes will occur.

However, Dudly and Jeremy Richardson (1945) have made it clear that this does not mean that institutions, policy networks, and public interests do not play an important role in the process of policy change. But what is discussed here is a radical policy change or a different side. Dudly and Jeremy Richardson (1945) understand the context of policy change, emphasizing identifying the factors that led to policy changes in the "third order/period" relating to the shift in the dominant paradigm. In terms of the dimensions of change, differentiates three orders. Order or first level is a regular adjustment to the policy instrument. The second order is the change of policy instruments to achieve the policy objectives. While the third order as the highest order is, the shift in purpose itself.

Efforts to analyze changes in policies under stability conditions can use or focus on looking at four "I", ie, First, Ideas. Second, Interests. Third, Institutions and, Fourth, Individuals. (Dudly and Jeremy Richardson, 1945: 222). Of the four "I" factors, Ideas and Individuals are independent variables, while ideas and interests have a close relationship that is almost difficult to separate. The link between stability and policy change is about how new ideas enter and absorb or ideas that transcend the importance of importance and institutions when the new idea is transplanted and brings about a third-order change, a paradigmatic shift in policy.

To see the dynamics of the policy of the position of deputy head of region in the instrument of the policy of local government law refers to what is delivered by Dudly and Richardson (1945), the change and the development of deputy head of blood policy is determined by, First, the existence of idea or idea. The change of policy on the position of deputy head of region, especially after the reformation of 1998, was based on the idea of democracy and decentralization, where the previous local government law depicts the centralized power of the new order (Law No. 5 of 1974), therefore after the elections of head elections and vice regional heads are carried out a package in the election. But this pattern is then found to have weaknesses where the deputy head of the region often conflicts with the head of the region.

Secondly, there is an interest. Changes and developments in the position of deputy regional head policy cannot be separated from the interests of political parties. With the current pattern in which the deputy head of the region is a must that can be taken from anywhere that meets the requirements and is selected in a package of candidate pairs. The phenomenon during this position of deputy head of the region that occurred many filled by candidates from political parties who passed the political lobbies and considered able to increase voting in the election. So that the presence of the regional deputy head of the local government is not directly elected by the community but determined by the Regional Head from the position of the State Civil Apparatus (ASN) caused a different reaction.

The proposal is considered by some politicians to be a weakening of political parties because political parties will lose one of their right to nominate their cadres in government. As stated by Sri Sultan Hamengkubuwono X appraised the proposal to appoint the Deputy Head of Region from the Civil Servants (PNS) that if really realized then it could harm the existence of political parties. Because if it is done, a political party which has the right to show its cadres as deputy regional head in a region will lose the right (www.tubesmedia.com).

In fact, the determination of the deputy heads of regional heads of political parties has been regarded as a source of conflict, as in Ramadan (2004: 93-94) examines the problems in the division of tasks between heads of government and government representatives, to date there are many factors that can be the cause who live in Indonesian politics, some can be drawn to the surface. These factors are as follows; (a) a duet of heads of government and Representatives of different parties. (b) the political interests behind the government and Vice-Head of government. By coming from different parties, it is very certain that the political interests underlying a head of government and the Deputy head of government will be different. The above description at least explains that the change and the development of the policy of the position of deputy head of region are strongly influenced by the existing interests.

Third, policy changes and developments are due to institutions. According to Suharto (2007: 44), public policy is essentially an expression of political will, ability, and commitment of the government. public policy can not be separated from the institutional context. The policy body then explains how government forms and systems operate. $\mathrm{He}$ also explains how the structure and hierarchy of government exercise political and administrative functions in accordance with its obligations.

An interesting thing to look at is to understand how ideas can be channeled into a binding public policy, to 
become a public policy idea requires a container called here with the institution as an arena that will bring about change, not just mere ideas anymore, institutions and ideas as the arena of change ". Dudly and Jeremy Richardson (1945) give a clear meaning that the idea will not give meaning if it is not channeled to the institution that will process an idea.

That the change of policy for the position of deputy head of region during the period of Indonesia cannot be separated from the role of the institution (Government and DPR). In the post-1998 reform era of the local government regulation policy instrument, there has been little change in the principle of conflict between the regional head and deputy regional head, so that the current law, Law no. Law No. 9 of 2015 contains only the deputy regional heads signing integrity pacts and being accountable to regional heads and the affirmation of deputy heads of districts is obliged to carry out joint tasks with the regional heads until the end of the tenure. There has been no fundamental change since the 1998 reforms because the institution is also not free from the ideas and interests of political parties, especially those in the legislature.

Fourth, Individuals. Individuals also play a very important role in relation to the prior three issues of ideas, interests, and institutions, the three will not work or change will not exist if there is no incentive from the individual itself as a driver of policy change. A policy change will be possible, if the individual who mobilizes the public policy is an individual who has a position or influence, such as the President, Minister, Board Member, Political Party Leader who are all considered key individuals. The role of key individuals is mentioned in some of the terminologies of "idea-makers" and policy entrepreneurs, who split ideas, injected them into advocacy coalitions, and then presented a firm leadership to the coalition. So far the fact that there is a change of policy cannot be separated from the individual members of DPR and the policy of the Minister of Home Affairs in charge of local government issues.

So from the four things above, then will be determined by time in the dynamics of change and policy development. Dudly and Jeremy Richardson (1945: 230) have said that "time is undoubtedly a key element in the radical process of policy change". Time plays a role in the occurrence of lobbying, understanding of a problem, the stability of a society's condition. In forwarding an idea or idea of public policy, so time plays another important role in an effort to change the policy.

The timing of the policy will certainly be filled with emerging issues. The issue according to Anderson (1990) is called the policy problem, condition or situation that produces needs or dissatisfaction on the part of people for which relief or redress is sought. It is important for policy actors to understand the developing issue by taking into account the patterns of the policy dynamics of the deputy head of the region.

\section{CONCLUSION}

The existence of the position of deputy head of region depends on the policy instrument in the form of laws regulating the regional autonomy. After the reform of 1998, policy instruments in the form of local government law have stipulated that the position of deputy head of region is a must and is a package of candidate pairs in the election process. The existence of the Deputy Head of Region has been colored with various problems or conflicts that have negative implications for the implementation of local government. On the basis of the background, it is necessary to approach a dynamics of public policy that sees the change and development of the policy of the position of deputy regional head in Indonesia.

Changes in policy and policy development of the position of deputy head of region in Indonesia so far because of four "I", namely, First, Idea. Second, Interests. Third, Institutions and, Fourth, Individuals. referring to it, it is important to be involved in policy-making to pay attention to the patterns that are formed in their respective times and the issues that develop in association with the position of deputy head of the region.

From each of the policy instruments in the form of local government law that has regulated the position of deputy head of region has given its own pattern. The existence of the position of deputy regional head in Indonesia starting from its simple position, not taken into account, and then began to be considered important for development. The presence of the deputy head of the region which was then considered important for the smooth running of the government and the regional development instead placed him in an unharmonious relationship with the regional head.

By looking at the existing pattern, it is important for the policymaker to change the policy of the position of the deputy head of the region that further ensures the stability and effectiveness of local government. Patterns that are currently formed more widely adopted the existing pattern of Law Number 32 The Year 2004 on Regional Government by adding some affirmations which, according to the authors do not provide much meaningful change. Perhaps the pattern that was formed during the period of Law No. 5 of 1974 on the Principles of Regional Government could be a consideration for the policymaker by making adjustments to the dynamics of existing government.

\section{REFERENCES}

[1] Dudley, Geofrey, and Jeremy Richardson, "Why Does Policy Changes", London, Routledge, 2000.

[2] Guyanie, Gugun El,. "Politik Hukum Pengaturan Jabatan Wakil Kepala Daerah Dalam Sistem Desentralisasi”. Yogyakarta: Jurnal Islamic Review, Vol. III No. 1, pp 63-90, April 2014.

[3] John, P., 'Is There Life After Policy Streams, Advocacy Coalitions, and Punctuations, Using Evolutionary Theory to Explain Policy Change?', The Policy Studies Journal, Vol. 31, No. 4481-498, 2003.

[4] Kansil, CST, "Pokok-Pokok Pemerintahan Daerah", Jakarta, Aksara Baru, 1979.

[5] Kay, Adrian, "The Dynamics of Public Policy: Theory and Evidence", USA, Edward Elgar, Cheltenham, UK and Northampton, MA, 2006.

[6] Labolo, Muhadam, 2015, "Dinamika Politik \& Pemerintahan Lokal", Bogor, Ghalia Indonesia

[7] Ndraha, Taliziduhu, "Kybernologi dan Kepamongprajaan", Tanggerang, Sirao Credentia Center, 2009.

[8] Nugraha, Nanang, "Model Kewenangan Wakil Kepala Daerah Dalam Pemerintahan Daerah”, Bandung, Refika Aditama, 2013.

[9] Nugroho, Riant, "Public Policy”, Jakarta, PT Gramedia, 2009.

[10] Ramadhan, Rizki Ananda, "Hubungan Internal Eksekutif: Mengagas pembagian Tugas dan Wewenang Presiden dan Wakil Presiden", Bandung, Jurnal Governance, Pusat Penelitian Kebijakan Publik dan Pengembangan Wilayah Lembaga Penelitian Universitas Padjadjaran, Vol. 2 No. 6 pp 90-100, April 2006.

[11] Stachowiak, Sarah, Pathways For Change: 10 Theories to Inform Advocacy and Policy Change Efforts, USA, ORS Impact, 2013.

[12] Suharto, Edi, "Kebijakan Sosial Sebagai Kebijakan Publik", Bandung, Alfabeta, 2007. 
[13] Wasistiono, Sadu, "Pemerintahan Lokal: Kontroversi Kedudukan, Tugas, Wewenang dan Tanggungjawabh Wakil Kepala Daerah", Pekanbaru: Pascasarjana Universitas Islam Riau, Bahan Kuliah Program Magister Ilmu Pemerintahan, 2012.

[14] Ardhana, (2011), Berita Nasional: Usulan Mentri Dalam Negri Wakil Kepala Daerah dari PNS. Di akses pada 27 Juni 2011, Dari World Wide Web: http://www.tubasmedia.com/pns-jadi-wakilkepala-daerah-rugikan-parpol/\#.WdM0Zo-0NH0

Legislation

[15] Undang-Undang Nomor 1 Tahun 1945 Tentang Kedudukan Komite Nasional Daerah

[16] Undang-Undang Nomor 22 Tahun 1948 Pokok Tentang Penetapan Aturan-Aturan Pokok Mengenai Pemerintahan Sendiri Di DaerahDaerah Yang Berhak Mengatur Dan Mengurus Rumah Tangganya Sendiri

[17] Undang-Undang Nomor 1 Tahun 1957 Tentang Pokok-Pokok Pemerintahan Daerah

[18] Penetapan Presiden Nomor 6 Tahun 1959 Tentang pemerintahan daerah

[19] Penetapan Presiden Nomor 2 Tahun 1960 Tentang Wakil Kepala Daerah Tingkat 1

[20] Undang-Undang Nomor 18 Tahun 1965 Tentang Pokok-Pokok Pemerintahan Daerah

[21] Undang-Undang Nomor 5 Tahun 1974 Tentang Tugas Pokok-Pokok Pemerintahan Daerah

[22] Undang-Undang Nomor 22 Tahun 1999 Tentang Pemerintahan Daerah

[23] Undang-Undang Nomor 32 Tahun 2004 Tentang Pemerintahan Daerah

[24] Undang-Undang Nomor 12 Tahun 2008 Tentang perubahan kedua atas undang-undang nomor 32 Tahun 2004 Tentang Pemerintahan Daerah

[25] Undang-Undang Nomor 23 Tahun 2014 Tentang Pemerintahan Daerah

[26] Undang-Undang Nomor 9 tahun 2015 Tentang Perubahan kedua atas Undang-Undang Nomor 23 Tahun 2014 Tentang Pemerintahan Daerah 